\title{
Factors Influencing Density of Age-0 Brown Trout and Brook Trout in the Au Sable River, Michigan
}

\author{
BRIAN J. MCRAE* \\ North Carolina Wildlife Resources Commission, Division of Inland Fisheries, \\ 1721 Mail Service Center, Raleigh, North Carolina 27699, USA \\ James S. Diana \\ School of Natural Resources and Environment, University of Michigan, \\ 430 East University, Ann Arbor, Michigan 48109, USA
}

\begin{abstract}
The density of juvenile trout is influenced by many factors, including water temperature, discharge, substrate composition, and the presence of aquatic vegetation. The objective of this study was to determine habitat conditions that influence densities of age-0 brown trout Salmo trutta and brook trout Salvelinus fontinalis in the Au Sable River, Michigan. Electrofishing was conducted with a 250-V DC tote barge at 12 sites throughout the Au Sable River watershed from June through August of 2000 and 2001. Densities of age-0 brown trout and brook trout varied significantly among sites located on the main stem as well as in tributaries. Analysis of covariance was used to evaluate annual interactions between age-0 trout densities and habitat variables. Simple and forward stepwise linear regressions were used to model brown trout and brook trout densities in relation to habitat variables. Percent gravel substrate and percent emergent vegetation accounted for $62 \%$ of the variance in age-0 brown trout density. In two separate analyses, mean minimum water temperature accounted for $31 \%$ of the variance in the density of age- 0 brook trout, whereas mean daily water temperature fluctuation accounted for $28 \%$ of the variance. Once habitat conditions that influence age- 0 fish production are identified, stocking programs should focus on areas where age-0 fish would be able to survive. If no suitable juvenile habitat is available, managers should instead invest effort in enhancing or creating nursery habitat. Such efforts will not only be valuable to the growth and survival of stocked individuals but will also have the benefit of enhancing the potential for the fishery to be sustained through natural reproduction.
\end{abstract}

The Au Sable River, Michigan, supports one of the most well-known trout fisheries in the eastern United States, and tourism related to this fishery is of great importance to the state's economy (Zorn and Sendek 2001). Consumers Power Co. owns and operates six hydroelectric dams on the mainstem Au Sable River. Dams alter the natural flow of rivers, prevent fish passage, and increase fish mortality due to turbines (Poff et al. 1997). Dams also adversely affect riparian vegetation, change river water temperature regimes, and increase downstream erosion by preventing longitudinal transport of sediment and woody debris (Petts 1984; Bednarek 2001). To enhance the trout fishery, the Michigan Department of Natural Resources (MDNR) annually stocks approximately 48,000 age-1 brown trout Salmo trutta in the reach of the river below Mio Dam. Conversely, brown trout have not been stocked in the Au Sable River above Mio Dam since 1974. Brook trout Salvelinus fontinalis have not been stocked in the river since

\footnotetext{
* Corresponding author: mcraebj@earthlink.net
}

Received September 14, 2003; accepted June 29, 2004
1992 (MDNR 1992, 2001). Both trout populations above Mio Dam are sustained through natural reproduction, whereas brown trout populations below the dam are assumed to require stocking to be sustained.

Many factors influence the production of juvenile fish. Juvenile trout abundance can be limited by substrate composition. Brown trout and brook trout prefer to spawn on gravel substrate (Brasch et al. 1973; Brynildson et al. 1973). Beard and Carline (1991) found that limited availability of spawning substrate was associated with low densities of age- 0 brown trout. Previous studies have concluded that habitat improvement efforts to increase gravel substrate can improve natural recruitment of brown trout (Meyers et al. 1992; Mesick 1995). Trout density is positively influenced by aquatic vegetation, which serves as an important source of cover for age-0 trout (Kocik and Taylor 1996; Maki-Petays et al. 1997). Water temperature has a direct effect on growth and survival of most fishes (Diana 1995), and may be the most important environmental variable limiting fish production in lotic systems (Baltz et al. 1987). Studies have indicated that elevated summer water tem- 


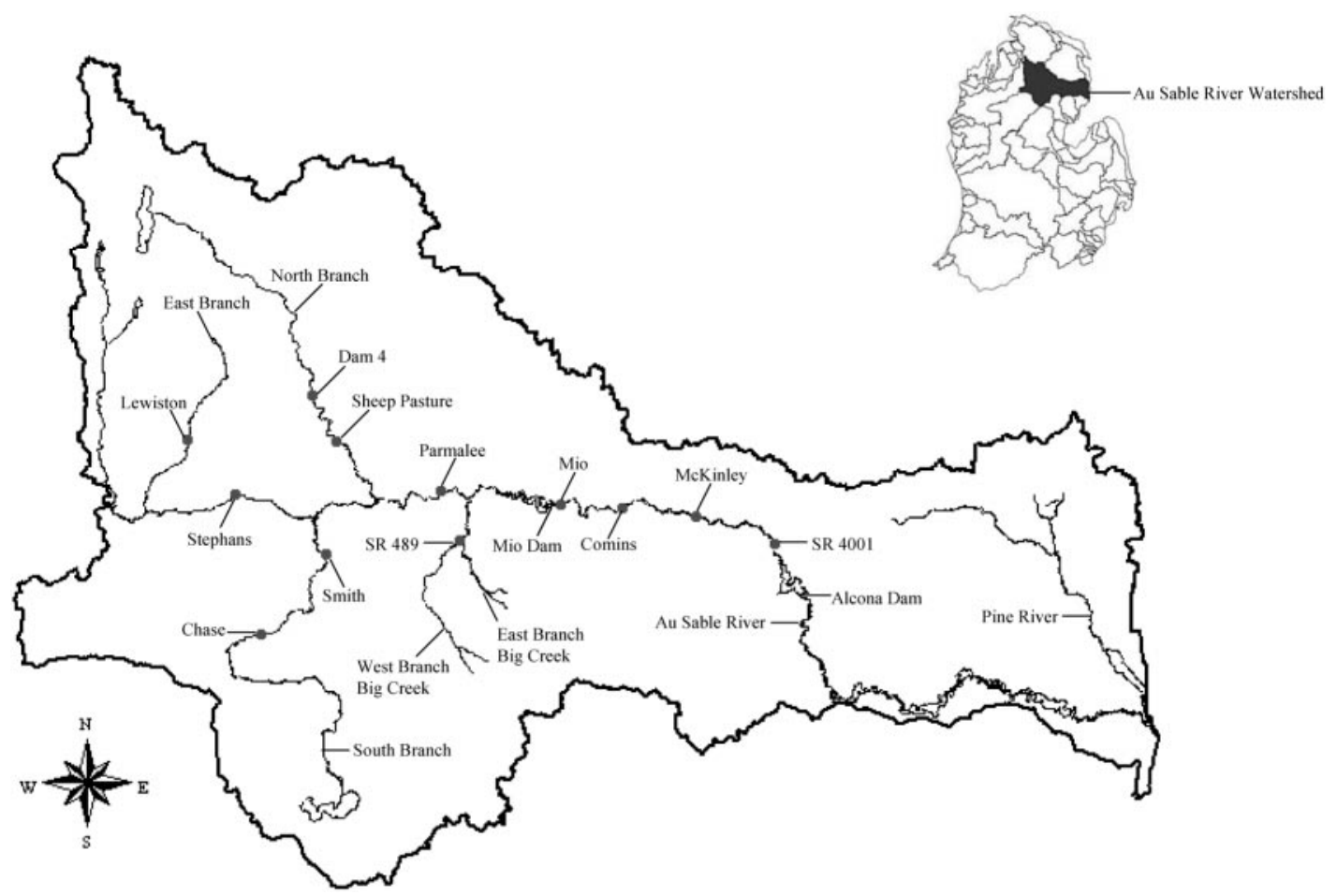

FIgURE 1.-Map of the Au Sable River, Michigan, where factors influencing age-0 brown trout and brook trout densities were investigated. Locations of major tributaries, the 12 study sites, Mio Dam, and Alcona Dam are identified; the abbreviation SR stands for state route.

peratures influence trout mortality (Stoneman and Jones 2000).

Even though many studies of the Au Sable River have been conducted, relatively little is known about specific habitat features that influence juvenile trout densities in this or other midwestern coldwater rivers. An understanding of the mechanisms that influence juvenile trout production will help managers sustain these valuable fisheries. The objective of this study was to determine habitat conditions that influence densities of age- 0 brown trout and brook trout in the Au Sable River.

\section{Methods}

Study area.-The Au Sable River is located in the north-central portion of Michigan's lower peninsula and is a major tributary to Lake Huron with a drainage area of approximately $4,662 \mathrm{~km}^{2}$ (Merron 1982). The watershed is comprised mostly of forest, ranging from aspen Populus spp., jack pine Pinus banksiana, and tag alder Alnus incana to coniferous swamp (Alexander and Shetter 1966). The geology is comprised primarily of moraine and glacial outwash (U.S. Forest Service 1980). The Au Sable River has six major hydroelectric dams on the main stem. This study was concentrated on the main stem and main tributaries above the uppermost dam, located in Mio, and also throughout the stretch of the main stem from Mio Dam to Alcona Pond (Figure 1). We focused on five river segments ranging in width between 8 and $44 \mathrm{~m}$ : the main-stem Au Sable, North Branch Au Sable, South Branch Au Sable, and East Branch Au Sable rivers, and Big Creek. Twelve locations were selected to create an even distribution of study areas throughout the watershed and to incorporate sites with varying stream size (Figure 1). At 10 sites, a 100-m reach was selected on one side of the river, and the sampled area extended 4 $\mathrm{m}$ out from the bank. On the two smaller tributaries, Big Creek and the East Branch, a 50-m reach with a mean width of $8 \mathrm{~m}$ was selected. At each site, a $400-\mathrm{m}^{2}$ area was sampled.

Field protocol.-At each site, a 250-V DC electrofishing tote barge with three probes was used to conduct depletion estimates. The depletion method has been used successfully to estimate the population size of age-0 trout (Mesick 1995; Van Zyll De Jong et al. 1997). We expected mortality of age- 0 trout to be lower with the depletion meth- 
od than with other methods because it involves less fish handling and does not require fin clipping or fish marking. Therefore, the Zippin (1958) depletion method was used to estimate age- 0 trout population size. Two-pass removal was conducted in 2000 and a third pass was added in 2001 in an attempt to increase precision in population estimates (Riley and Fausch 1992). Each site was electrofished once per month from June through $\mathrm{Au}$ gust during 2000 and 2001; approximately $30 \mathrm{~d}$ separated each sampling period. During each pass, the entire $400-\mathrm{m}^{2}$ sample area was thoroughly electrofished in an upstream direction, and all encountered fish were collected. After each pass, all fish were placed in flow-through buckets within the stream. All fish were counted after the final pass was completed. Total lengths (nearest $\mathrm{mm}$ ) and weights (nearest g) of up to 20 brown trout and 20 brook trout were measured from both pass one and pass two. Length-frequency histograms were used to separate brown trout and brook trout into age 0 or older age-classes (Moyle and Vondracek 1985). In August 2001, scales were removed from a subsample of brown trout and brook trout to verify age-classes (Griffith and Smith 1993). All collected fish were returned to the river after handling.

Changes in population density from June to July and from July to August were used to estimate the apparent loss rate of age- 0 brown trout and brook trout at each site during both years. Percent survival was used to represent the apparent loss rate and was calculated based on the following formula (Everhart et al. 1975):

$$
\% S=\left(\frac{N_{t+1}}{N_{t}}\right) \cdot 100,
$$

where $\% S$ is percent survival, $N_{t}$ is the estimated fry density at time $t$, and $N_{t+1}$ is the estimated density of fry at time $t+1$.

Water temperature was measured hourly by Onset HOBO instream data recorders at 10 of the 12 sites. The HOBO data recorders were not used at Mio or State Route (SR) 4001 because the U.S. Geological Survey provided data from gauges with temperature recorders at those sites. The HOBO recorders were placed at each site in late April and removed in early September. Mean, minimum, and maximum summer (June through August) water temperatures were calculated for each site in 2000 and 2001. The mean daily water temperature fluctuation and accumulated degree-days during sum- mer 2000 and 2001 were also calculated for each site.

Stream velocity was measured with a MarshMcBirney electronic current meter. Two transects located perpendicular to the main current were made at the upstream and downstream end of each reach, and velocity was measured at 0.6 times total depth for $1.0-\mathrm{m}$ intervals along each transect across the entire stream. The total depth at each $1.0-\mathrm{m}$ interval and the total width to the edge of the wetted bank of each transect were also recorded. A second stream velocity measurement was calculated for the lateral habitat; only values from within the first $4 \mathrm{~m}$ of each transect were used in calculations. Discharge and lateral habitat discharge for each site were calculated as the product of width, mean depth, and mean velocity, and discharge values were then averaged for the two transects. Measurements were made in mid-August, when flows were low and stream widths at most sites were wadeable. At McKinley and SR 4001, we were unable to wade the entire stream width; therefore, measurements at these sites were made from a canoe that was held stationary by a rope stretched across the river.

Percent substrate type, woody debris, and submerged vegetation were measured by use of an aquascope equipped with a 50-point dot matrix on the lens. Ten transects oriented perpendicular to the main current and spaced $10 \mathrm{~m}$ apart were created within the $400-\mathrm{m}^{2}$ sample area. Along each transect, the total number of dots covering a selected variable were recorded and divided by the total number of dots available. The dot matrix method for substrate is commonly used in rapid visual assessment of periphyton (Barbour et al. 1999). Its advantages are that human judgment is not incorporated and a more quantitative assessment of surficial substrate composition is determined. This method therefore provides a more direct analysis of habitat variables influencing trout densities compared to other available methods. Classifications for substrate type followed a modified Wentworth scale (modified from Bain et al. 1985): silt/sand (particles $<2 \mathrm{~mm}$ ), gravel (2.1$64 \mathrm{~mm})$, cobble (64.1-256 mm), and boulder $(>256 \mathrm{~mm})$. Woody debris was defined as any wood structure with a length of $1 \mathrm{~m}$ or greater and a mean diameter over $10 \mathrm{~cm}$ situated with at least $15 \mathrm{~cm}$ of water beneath it (Fausch and Northcote 1992). Only woody debris in contact with water at the time of sampling was recorded. Submerged vegetation that covered an area of at least $4 \mathrm{~cm}^{2}$ was recorded as available habitat. Percent emer- 
gent vegetation was calculated as the total length of emergent vegetation extending at least $15 \mathrm{~cm}$ from the bank divided by the total length of the stream reach.

Statistical analyses.-Population densities were $\log _{e}(x+1)$ transformed and habitat conditions $(\%)$ were arcsine-square-root transformed for conformance with the assumptions of parametric statistics and linear regression. In order to compare results from 2000 and 2001, we required age-0 trout population estimates to be similar between the two-pass removal method used in 2000 and the three-pass removal method used in 2001. To compare removal methods, we used 2001 data to derive population estimates at each site from both twopass and three-pass equations. Simple linear regression and a paired $t$-test were used to evaluate population estimates derived from both removal methods. One-way analysis of variance (ANOVA) tests were used to evaluate differences in population density among sites. Differences in the apparent loss rate among sites were evaluated with a Kruskal-Wallis nonparametric one-way ANOVA. In cases for which apparent loss rates were not significantly different among sites, monthly population densities were averaged across sites to account for the assumption of spatial independence. Pearson's correlation was used to evaluate relationships between habitat variables and between age- 0 trout densities and noncollinear habitat variables. Two-way ANOVA was used to evaluate interannual variation in trout densities and sample sites. Analysis of covariance was used to evaluate annual interactions between population densities and selected habitat variables. When interactions were not significant, data from both years were combined and analyzed with simple and forward stepwise linear regressions. Regressions were used to create models for predicting age-0 brown trout and brook trout densities from habitat variables. Separate regressions were used to analyze correlated habitat variables. The significance level $(\alpha)$ used for inclusion of variables in stepwise models was 0.05 . Appropriate residual plots were analyzed to verify that regression assumptions were not violated. All statistical analyses were performed with the Statistical Package for the Social Sciences version 10.0 (SPSS 1998), and results were considered statistically significant at $P$-values less than 0.05 .

\section{Results}

Brown trout densities were significantly different among sites where brown trout were observed at least once during the sampling period (2000: $\mathrm{df}$ $=9, F=8.24, P<0.001 ; 2001: \mathrm{df}=9, F=$ 14.17, $P<0.001)$. Brook trout densities were also significantly different among sites where brook trout were observed at least once during the sampling period (2000: $\mathrm{df}=6, F=13.08, P<0.001$; 2001: df $=9, F=14.93, P<0.001)$. Density estimates for both species varied greatly among sites throughout the watershed (Figure 2a, b). Apparent loss rates among sample sites were not significantly different for either brown trout or brook trout in 2000 (brown trout, $P=0.22$; brook trout, $P=0.39$ ) or 2001 (brown trout, $P=0.37$; brook trout, $P=0.27$ )

Habitat conditions varied throughout the Au Sable River watershed during the study period (Table $1)$. Emergent vegetation was found in greatest abundance at Sheep Pasture $(56.6 \%)$, whereas a small percentage of the stream bank supported emergent vegetation at McKinley $(0.9 \%)$. The largest percentage of gravel substrate was found at Comins $(81.8 \%)$, whereas only a small percentage of the substrate at Lewiston consisted of gravel $(5.9 \%)$. Mean summer water temperatures were $15.5^{\circ} \mathrm{C}$ at Stephans and $15.6^{\circ} \mathrm{C}$ at SR 489 , whereas all sites below Mio Dam had mean water temperatures of at least $19.0^{\circ} \mathrm{C}$.

Regressions demonstrated that brown trout and brook trout population estimates were similar between two-pass and three-pass depletion methods $\left(r^{2}=0.98, P<0.001\right)$. The estimated intercept of the regression was not significantly different from zero $\left(B_{0} ; P=0.16\right)$; however, the estimated slope of the line differed significantly from 1.0 (slope $=1.1, \mathrm{SE}=0.025)$. Even though the regression slope did not equal 1.0, no significant differences were found between population estimates calculated from two- and three-pass depletion methods $(t=1.64, P=0.11)$. The three-pass removal method decreased the variability in the population estimates; however, the actual population estimates were similar between the two methods.

Brown trout density was similar between 2000 and $2001(F=0.82, P=0.39)$. Data from the two years were combined, and no significant annual interaction existed between pooled brown trout densities and percent emergent vegetation $(F=$ $0.29, P=0.60)$ or percent gravel values $(F=0.67$, $P=0.42$ ). A multiple regression including the pooled data from 2000 and 2001 indicated that percent emergent vegetation and percent gravel substrate accounted for $62 \%$ of the variance in brown trout density (Table 2).

Mean minimum water temperature and mean 

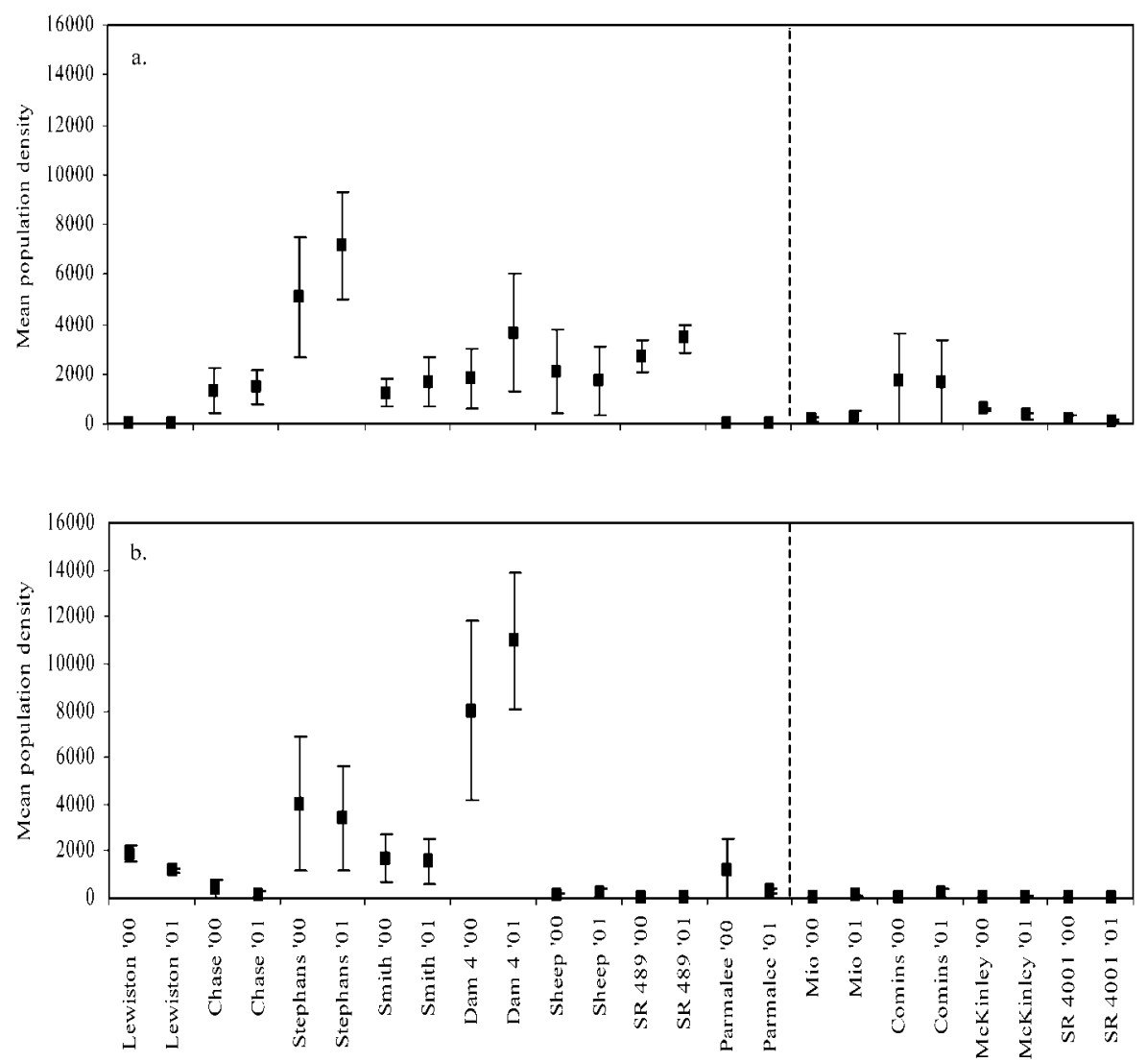

FIGURE 2.- Mean population densities (fish/ha $\pm 95 \%$ confidence limits) for (a) age-0 brown trout and (b) age0 brook trout at 12 sites in the Au Sable River system, Michigan, during June through August in 2000 and 2001. The dashed line represents Mio Dam; sites are ordered by location upstream or downstream from Mio Dam.

daily water temperature fluctuation were highly correlated (2000: $r=-0.88 ; 2001: r=-0.89$; combined: $r=-0.79)$. Brook trout densities in 2000 and 2001 were similar $(F=0.52, P=0.48)$. Data from the two years were therefore combined. We found no significant annual interaction between pooled brook trout densities and mean minimum water temperature $(F=0.26, P=0.62)$ or mean daily water temperature fluctuation $(F=$ $0.29, P=0.59)$. A simple regression that included pooled data from 2000 and 2001 indicated that mean minimum water temperature accounted for $31 \%$ of the variance in brook trout density (Table 2 ). A separate regression of the pooled data indicated that mean daily water temperature fluctuation accounted for $28 \%$ of the variance in brook trout density (Table 2).

\section{Discussion}

Percentages of gravel and emergent vegetation were the most important variables correlated with the density of age-0 brown trout throughout the $\mathrm{Au}$ Sable River. Juvenile brown trout occupied sites with high gravel percentages because gravel is the preferred substrate of brown trout for spawning and as fry nursery habitat (O' Connor and Power 1976; House and Boehne 1986; Meyers et al. 1992). Mesick (1995) found that after gravel was added to a site, redd density was highest in the improved segment and density of age- 0 brown trout increased to three times the original level. Additionally, brown trout fry use the interstitial area in gravel as cover from predation and as refuge from high discharge (Heggenes 1988; Borgstrom et al. 1993; Greenberg 1994).

As with gravel, emergent vegetation is an important habitat feature for juvenile brown trout because they can use it as cover from predation. This was obvious during our collections, as most trout were collected in the vegetated portions of each reach. Many studies have indicated that aquatic vegetation is used as cover by age- 0 brown trout 
TABLE 1.-Mean values of habitat conditions measured at sample sites in the Au Sable River watershed, Michigan, during 2000 and 2001. Submerged vegetation was only measured in 2001.

\begin{tabular}{|c|c|c|c|c|c|c|c|c|c|c|c|}
\hline Sample site & $\begin{array}{l}\text { Width } \\
(\mathrm{m})\end{array}$ & $\begin{array}{l}\text { Depth } \\
(\mathrm{m})\end{array}$ & $\begin{array}{c}\text { Discharge } \\
\left(\mathrm{m}^{3} / \mathrm{s}\right)\end{array}$ & $\begin{array}{c}\text { Sand } \\
(\%)\end{array}$ & $\begin{array}{c}\text { Gravel } \\
(\%)\end{array}$ & $\begin{array}{c}\text { Cobble } \\
(\%)\end{array}$ & $\begin{array}{c}\text { Boulder } \\
(\%)\end{array}$ & $\begin{array}{l}\text { Woody } \\
\text { debris } \\
(\%)\end{array}$ & $\begin{array}{c}\text { Emergent } \\
\text { vegetation } \\
(\%)\end{array}$ & $\begin{array}{c}\text { Mean } \\
\text { temperature } \\
\left({ }^{\circ} \mathrm{C}\right)\end{array}$ & $\begin{array}{c}\text { Submerged } \\
\text { vegetation } \\
(\%)\end{array}$ \\
\hline \multicolumn{12}{|c|}{ East Branch Au Sable River } \\
\hline Lewiston & 8.9 & 0.32 & 0.47 & 94.1 & 5.9 & & & 13 & 3.5 & 16.3 & 10.8 \\
\hline \multicolumn{12}{|c|}{ South Branch Au Sable River } \\
\hline Chase & 14.5 & 0.39 & 2.4 & 77.6 & 20.4 & 2.0 & & 7.4 & 21.6 & 17.3 & 6.4 \\
\hline Smith & 17.3 & 0.49 & 3.4 & 61.5 & 27.1 & 11.1 & 0.3 & 8.5 & 6.2 & 16.8 & 0.4 \\
\hline \multicolumn{12}{|c|}{ North Branch Au Sable River } \\
\hline Dam 4 & 21.5 & 0.26 & 3.1 & 31.3 & 59.3 & 9.4 & & 4.2 & 27.7 & 17.3 & 47.9 \\
\hline Sheep Pasture & 19.8 & 0.44 & 3.3 & 47.6 & 42.5 & 9.6 & 0.3 & 4.1 & 56.6 & 16.9 & 16.1 \\
\hline \multicolumn{12}{|l|}{ Big Creek } \\
\hline State Route 489 & 8.2 & 0.22 & 0.61 & 17.3 & 78.4 & 4.3 & & 3.6 & 25.9 & 15.6 & 2.2 \\
\hline \multicolumn{12}{|c|}{ Main-stem Au Sable River } \\
\hline Stephans & 19.9 & 0.46 & 4.5 & 30.1 & 68.8 & 1.1 & & 3.6 & 47.2 & 15.5 & 0.3 \\
\hline Parmalee & 30.1 & 0.90 & 15.8 & 19.8 & 56.3 & 23.4 & 0.5 & 3.4 & 1.4 & 18.5 & 0.7 \\
\hline $\mathrm{Mio}^{\mathrm{a}}$ & 49.7 & 0.55 & 19.5 & 37.8 & 47.8 & 11.3 & 3.1 & 12.8 & 1.3 & 19.7 & 0.6 \\
\hline Comins & 34.8 & 0.39 & 7.7 & 4.8 & 81.8 & 13.4 & & & 12.1 & 19.9 & 55.1 \\
\hline McKinley & 40.3 & 0.92 & 16.6 & 25 & 58.4 & 16 & 0.6 & 7.8 & 0.9 & 19.0 & \\
\hline State Route $4001^{\mathrm{a}}$ & 46.3 & 0.80 & 18.4 & 20.6 & 28.7 & 48 & 2.7 & 0.8 & 3.2 & 19.1 & \\
\hline
\end{tabular}

a Water temperature data were obtained from U.S. Geological Survey gauging stations at these sites.

(Mortensen 1977; Glova and Duncan 1985; MakiPetays et al. 1997). Kocik and Taylor (1996) found that aquatic vegetation was the most commonly used cover type for brown trout fry in Gilchrist Creek, Michigan, a tributary to Lake Huron. Aquatic vegetation also increases the production of aquatic macroinvertebrates (Egglishaw and Shackley 1977), which are in turn preyed upon by the juvenile trout (Jowett 1992).

Water temperature was the most important variable correlated to age- 0 brook trout density throughout the Au Sable River watershed. Whether the specific variable analyzed was mean minimum water temperature or diel water temperature fluctuation, the river's thermal regime had an overriding effect on the density of young brook trout. Mean water temperature throughout the watershed was $17.2^{\circ} \mathrm{C}$ in 2000 and $18.1^{\circ} \mathrm{C}$ in 2001 ; the optimal range for growth and survival of juvenile brook trout is $12-15^{\circ} \mathrm{C}$, and the maximum tolerance level is $18^{\circ} \mathrm{C}$ (McCormick et al. 1972). Given that mean water temperatures were close to their maximum tolerance, it is not surprising that temperature was the overriding factor influencing age0 brook trout density in the study area. Similarly, MacCrimmon and Campbell (1969) found that maximum summer water temperature was the dominant factor limiting brook trout distribution. Various other studies have also contended that water temperature is the most important variable limiting brook trout abundance (Bowlby and Roff 1986; Baird and Krueger 2003). Further, the association of brook trout with sites that have large daily temperature fluctuations and lower minimum water temperatures may exist because such conditions limit exposure to temperatures above their maximum tolerance level.

Dams interrupt the connectivity of river ecosystems, change river water temperature regimes, and prevent longitudinal transport of sediment and woody debris. A general decline in brown trout and brook trout densities was found at the sites

TABLE 2.- Summary of regression models describing age-0 brown trout and age-0 brook trout densities in relation to habitat conditions in the Au Sable River watershed, Michigan.

\begin{tabular}{llrrrr}
\hline \multirow{2}{*}{ Species } & \multicolumn{1}{c}{ Habitat variable } & Pariable $P$ & $r$ & Adjusted & \\
& \multicolumn{1}{c}{ Partial } & Model $P$ \\
\hline Brown trout & Emergent vegetation $(\%)$ & $<0.001$ & 0.73 & 0.62 & $<0.001$ \\
& Gravel substrate $(\%)$ & 0.020 & 0.48 & & \\
Brook trout & Mean minimum water temperature $\left({ }^{\circ} \mathrm{C}\right)$ & 0.005 & & 0.31 & 0.005 \\
Brook trout & Mean daily water temperature fluctuation $\left({ }^{\circ} \mathrm{C}\right)$ & 0.008 & & 0.28 & 0.008 \\
\hline
\end{tabular}


below Mio Dam. Mio Dam likely has a large effect on the habitat conditions necessary to support juvenile trout production in the reach of the river below the dam. A decreased occurrence of emergent vegetation in the reach below Mio Dam may explain why age-0 brown trout densities tended to be lower at these sites. Increased minimum water temperature and decreased water temperature fluctuation probably contributed to the limited age- 0 brook trout production in the area downstream of Mio Dam.

The results from this study may have been skewed by some of the assumptions made during the analysis. Densities of brown trout and brook trout were averaged at each site in both years to account for spatial independence. It is possible that the monthly density estimates may have been skewed by emigration, immigration, or mortality rates; however, no significant differences in apparent loss rates were detected among sites. Further, Egglishaw and Shackley (1977) analyzed declines in trout fry population density from June to July, and determined that under normal flow conditions, emigration would account for only a small part of the decline. The removal method assumes the following: (1) populations are stationary during the sampling period (no immigration or emigration), (2) the probability of capture is equal for all fish and is constant between passes, and (3) sampling effort and weather conditions are constant between passes (Zippin 1958). The stationary population assumption may have been violated because the size of the river at most sites prevented us from using block nets to restrict migration. During analysis of survey methods for young trout and salmon, Heggenes et al. (1990) noted that the use of block nets during electrofishing did not increase the number of fish caught near the nets, and therefore the authors discontinued use of the nets during further sampling. Similarly, Slawski and Ehlinger (1998) indicated that block nets did not increase sampling efficiency during electrofishing surveys of trout in a Wisconsin stream. Our population estimates may have had a slight negative bias because of emigration from the sample sites between electrofishing passes, but density estimates at each site in the watershed should have been equally influenced. Sampling effort was kept constant by thoroughly electrofishing all available habitats during each pass and by spending equal amounts of time (approximately $35 \mathrm{~min}$ ) on each pass whether fish were abundant or not. Time between each pass was kept to a minimum to ensure that weather conditions remained constant. Interspe- cific competition between brown trout and brook trout may have influenced the density measures of each species. Fausch and White (1986) studied interactions between juvenile brown trout and brook trout and concluded that the two species competed in the same hierarchy structure. Therefore, at sites that contained high densities of trout, the presence of one species might have resulted in interactions that reduced the presence of the other.

It is important to determine the specific habitat variables limiting production of age- 0 fish when managing riverine fisheries. Once these variables are identified, stocking programs should concentrate effort in areas where future populations of age-0 fish would be able to survive. If no suitable juvenile habitat is available, managers should instead invest effort into enhancing or creating nursery habitat. Such efforts will not only be valuable to the growth and survival of stocked individuals but will also have the benefit of enhancing the potential for the fishery to be sustained through natural reproduction. Put-and-take fisheries are expensive and do not proactively address the issue of sustainability. Restoration efforts that focus on juvenile habitats may enhance fishery production and sustainability.

\section{Acknowledgments}

Funding for this research was provided primarily through the Federal Energy Regulatory Commission's Habitat Improvement Fund, administered by the MDNR. Additional funding was provided by the Rackham School of Graduate Studies at the University of Michigan, and the Kalamazoo Chapter of Trout Unlimited. We thank the staff of the MDNR Institute for Fisheries Research, Ann Arbor, and the MDNR Grayling field unit, who provided valuable assistance and equipment. We are grateful for the support of the many volunteers who helped collect field data. We thank the three anonymous reviewers for their valuable insight and detailed critiques on earlier drafts of this manuscript.

\section{References}

Alexander, G. R., and D. S. Shetter. 1966. Fishing and boating on segments of the Au Sable River in Michigan, 1960-63. Michigan Department of Conservation, Institute for Fisheries Research Report 1722, Ann Arbor.

Bain, M. B., J. T. Finn, and H. E. Booke. 1985. Quantifying stream substrate for habitat analysis studies. North American Journal of Fisheries Management 5:499-501.

Baird, O. E., and C. C. Krueger. 2003. Behavioral ther- 
moregulation of brook and rainbow trout: comparison of summer habitat use in an Adirondack river, New York. Transactions of the American Fisheries Society 132:1194-1206.

Baltz, D. M., B. Vondracek, L. R. Brown, and P. B. Moyle. 1987. Influence of temperature on microhabitat choice by fishes in a California stream. Transactions of the American Fisheries Society 116: 12-20.

Barbour, M. T., J. Gerritsen, B. D. Snyder, and J. B. Stribling. 1999. Rapid bioassessment protocols for use in streams and wadeable rivers: periphyton, benthic macroinvertebrates, and fish, 2nd edition. U.S. Environmental Protection Agency, EPA 841-B-99002, Washington, D.C.

Beard, T. D., Jr., and R. F. Carline. 1991. Influence of spawning and other stream habitat features on spatial variability of wild brown trout. Transactions of the American Fisheries Society 120:711-722.

Bednarek, A. T. 2001. Undamming rivers: a review of the ecological impacts of dam removal. Environmental Management 27:803-814.

Borgstrom, R., J. Heggenes, and T. G. Northcote. 1993. Regular, cyclic oscillations in cohort strength in an allopatric population of brown trout, Salmo trutta L. Ecology of Freshwater Fish 2:8-15.

Bowlby, J. N., and J. C. Roff. 1986. Trout biomass and habitat relationships in southern Ontario streams. Transactions of the American Fisheries Society 115: 503-514.

Brasch, J., J. McFadden, and S. Kmiotek. 1973. Brook trout: life history, ecology, and management. Wisconsin Department of Natural Resources, Publication 226, Madison.

Brynildson, O. M., V. A. Hacker, and T. A. Klick. 1973. Brown trout: life history, ecology, and management. Wisconsin Department of Natural Resources, Publication 234, Madison.

Diana, J. S. 1995. Biology and ecology of fishes. Biological Sciences Press, Carmel, Indiana.

Egglishaw, H. J., and P. E. Shackley. 1977. Growth, survival, and production of juvenile salmon and trout in a Scottish stream, 1966-75. Journal of Fish Biology 11:647-672.

Everhart, W. H., A. W. Eipper, and W. D. Youngs. 1975. Principles of fishery science. Cornell University Press, Ithaca, New York.

Fausch, K. D., and T. G. Northcote. 1992. Large woody debris and salmonid habitat in a small coastal British Colombia stream. Canadian Journal of Fisheries and Aquatic Sciences 49:682-693.

Fausch, K. D., and R. J. White. 1986. Competition among juveniles of coho salmon, brook trout, and brown trout in a laboratory stream and implications for Great Lakes tributaries. Transactions of the American Fisheries Society 115:363-381.

Glova, G. J., and M. J. Duncan. 1985. Potential effects of reduced flows on fish habitats in a large braided river, New Zealand. Transactions of the American Fisheries Society 114:165-181.

Greenberg, L. A. 1994. Effects of predation, trout density, and discharge on habitat use by brown trout,
Salmo trutta, in artificial streams. Freshwater Biology 32:1-11.

Griffith, J. S., and R. W. Smith. 1993. Use of winter concealment cover by juvenile cutthroat and brown trout in the South Fork of the Snake River, Idaho. North American Journal of Fisheries Management 13:823-830.

Heggenes, J. 1988. Substrate preferences of brown trout fry (Salmo trutta) in artificial stream channels. Canadian Journal of Fisheries and Aquatic Sciences 45:1801-1806.

Heggenes, J., A. Brabrand, and S. J. Saltveit. 1990. Comparison of three methods for studies of stream habitat use by young brown trout and Atlantic salmon. Transactions of the American Fisheries Society 119:101-111.

House, R. A., and P. L. Boehne. 1986. Evaluation of instream structures on salmonid habitat and populations in Tobe Creek, Oregon. North American Journal of Fisheries Management 6:38-46.

Jowett, I. G. 1992. Models of the abundance of large brown trout in New Zealand rivers. North American Journal of Fisheries Management 12:417-432.

Kocik, J. F., and W. W. Taylor. 1996. Effect of juvenile steelhead on juvenile brown trout habitat use in a low-gradient Great Lakes tributary. Transactions of the American Fisheries Society 125:244-252.

MacCrimmon, H. R., and J. S. Campbell. 1969. World distribution of brook trout, Salvelinus fontinalis. Journal of the Fisheries Research Board of Canada 26:1699-1725.

Maki-Petays, A., T. Muotka, A. Huusko, P. Tikkanen, and P. Kreivi. 1997. Seasonal changes in habitat use and preference by juvenile brown trout, Salmo trutta, in a northern boreal river. Canadian Journal of Fisheries and Aquatic Sciences 54:520-530.

McCormick, J. H., K. E. F. Hokanson, and B. R. Jones. 1972. Effects of temperature on growth and survival of young brook trout, Salvelinus fontinalis. Journal of the Fisheries Research Board of Canada 29:1107-1112.

Merron, G. S. 1982. Growth rate of brown trout (Salmo trutta) in areas of the Au Sable River, Michigan, before and after domestic sewage diversion. Michigan Department of Natural Resources, Fisheries Research Report 1900, Ann Arbor.

Mesick, C. F. 1995. Response of brown trout to streamflow, temperature, and habitat restoration in a degraded stream. Rivers 5:75-95.

Meyers, L. S., T. F. Thuemler, and G. W. Kornely. 1992. Seasonal movements of brown trout in northeast Wisconsin. North American Journal of Fisheries Management 12:433-441.

MDNR (Michigan Department of Natural Resources). 1992. Michigan fish stocking record. MDNR, Fisheries Division, Lansing.

MDNR (Michigan Department of Natural Resources). 2001. Michigan fish stocking record. MDNR, Fisheries Division, Lansing.

Mortensen, E. 1977. Density-dependent mortality of trout fry (Salmo trutta L.) and its relationship to the 
management of small streams. Journal of Fish Biology 11:613-617.

Moyle, P. B., and B. Vondracek. 1985. Persistence and structure of the fish assemblage in a small California stream. Ecology 66:1-13.

O'Connor, J. F., and G. Power. 1976. Production by brook trout (Salvelinus fontinalis) in four streams in the Matamek watershed, Quebec. Journal of the Fisheries Research Board of Canada 33:6-18.

Petts, G. E. 1984. Impounded rivers: perspective for ecological management. Wiley, New York.

Poff, N. L., J. D. Allan, M. B. Bain, J. R. Karr, K. L. Prestegaard, B. D. Richter, R. E. Sparks, and J. C. Stromberg. 1997. The natural flow regime. Bioscience 47:769-784.

Riley, S. C., and K. D. Fausch. 1992. Underestimation of trout population size by maximum-likelihood removal estimates in small streams. North American Journal of Fisheries Management 12:768-776.

Slawski, T. M., and T. J. Ehlinger. 1998. Fish habitat improvement in box culverts: management in the dark? North American Journal of Fisheries Management 18:676-685.
SPSS. 1998. Statistical software, version 10.0. SPSS, Chicago.

Stoneman, C. L., and M. L. Jones. 2000. The influence of habitat features on the biomass and distribution of three species of southern Ontario stream salmonids. Transactions of the American Fisheries Society 129:639-657.

U.S. Forest Service. 1980. Au Sable River: wild and scenic river final study report and environmental impact statement. U.S. Forest Service, Washington, D.C.

Van Zyll De Jong, M. C., I. G. Cowx, and D. A. Scruton. 1997. An evaluation on instream habitat restoration techniques on salmonid populations in a Newfoundland stream. Regulated Rivers: Research and Management 13:603-614.

Zippin, C. 1958. The removal method of population estimation. Journal of Wildlife Management 22:8290.

Zorn, T. G., and S. P. Sendek. 2001. Au Sable River assessment. Michigan Department of Natural Resources, Fisheries Special Report 26, Lansing. 